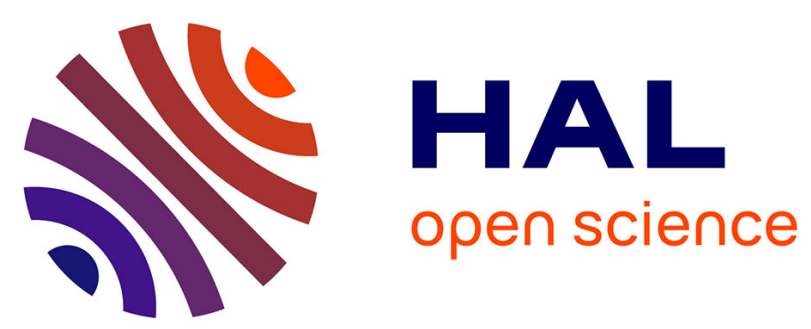

\title{
Letter to the Editor: Abdominal Surgery in Idiopathic Noncirrhotic Portal Hypertension: Is Preemptive TIPS Reducing Postoperative Complications?
}

Emanuele Felli, Antonio Saviano, Simona Tripon, Thomas F Baumert, Patrick Pessaux

\section{To cite this version:}

Emanuele Felli, Antonio Saviano, Simona Tripon, Thomas F Baumert, Patrick Pessaux. Letter to the Editor: Abdominal Surgery in Idiopathic Noncirrhotic Portal Hypertension: Is Preemptive TIPS Reducing Postoperative Complications?. Hepatology, In press, 10.1002/hep.30985 . hal-02379929

\section{HAL Id: hal-02379929 https://hal.science/hal-02379929}

Submitted on 25 Nov 2019

HAL is a multi-disciplinary open access archive for the deposit and dissemination of scientific research documents, whether they are published or not. The documents may come from teaching and research institutions in France or abroad, or from public or private research centers.
L'archive ouverte pluridisciplinaire HAL, est destinée au dépôt et à la diffusion de documents scientifiques de niveau recherche, publiés ou non, émanant des établissements d'enseignement et de recherche français ou étrangers, des laboratoires publics ou privés. 
Article type : Correspondence

\section{Letter to the Editor: Abdominal Surgery in Idiopathic Noncirrhotic Portal Hypertension: Is Preemptive TIPS Reducing Postoperative Complications?}

Emanuele Felli, ${ }^{1,2^{*}}$ Antonio Saviano, ${ }^{1-3^{*}}$ Simona Tripon, ${ }^{1,2}$ Thomas F. Baumert, ${ }^{1-3}$ and Patrick Pessaux ${ }^{1-3}$

1Department of General, Digestive, and Endocrine Surgery, Strasbourg University Hospitals, Institut Hospitalo-Universitaire, Strasbourg, France; ${ }^{2}$ Institut of Viral and Liver Disease, Inserm U1110, Strasbourg, France; 3University of Strasbourg, Strasbourg, France.

*These authors contributed equally to this work.

Correspondence should be addressed to:

Emanuele Felli, M.D.,

Pôle Hépato-digestif, Nouvel Hôpital Civil

1, Place de l'Hôpital, 67091 Strasbourg cedex, France

Antonio Saviano, M.D.,

Institut de Recherche sur les Maladies Virales et Hépatiques, Inserm U1110

3, rue de Koeberlé, 67000 Strasbourg, France

+33(0) 368853727

This article has been accepted for publication and undergone full peer review but has not been through the copyediting, typesetting, pagination and proofreading process, which may lead to differences between this version and the Version of Record. Please cite this article as doi: 10.1002/HEP.30985

This article is protected by copyright. All rights reserved 
E-mail: emanuele.felli@chru-strasbourg.fr; saviano@unistra.fr

Abbreviations: INCPH, idiopathic noncirrhotic portal hypertension; TIPS, transjugular intrahepatic portosystemic shunt.

\section{To the Editor}

We read with great interest the article by Elkrief et al. reporting long-term outcomes of abdominal surgery in patients with idiopathic noncirrhotic portal hypertension $(\mathrm{INCPH})^{(1)}$ In a subgroup analysis, the authors compared the outcome of patients who had $(n=33)$ or did not have $(n=10)$ a preemptive transjugular intrahepatic portosystemic shunt (TIPS), showing that TIPS before surgery had no significant impact on postoperative outcomes. This retrospective subgroup analysis had some limitations. The comparison of the clinical characteristics between the groups was performed on the data after TIPS placement, and the small sample size reduced the statistical power of the analysis. These data are still preliminary to draw any firm conclusion-as already discussed by the authors-but could potentially dissuade clinicians in using preemptive TIPS in this clinical context.

$\mathrm{INCPH}$ is a rare disease, and it is unlikely that survival analysis of larger cohorts will be available in the immediate future. To help readers and to highlight the magnitude of the differences between the two groups, we reanalyzed the clinical and postoperative data reported by Elkrief et al. and calculated the effect size using logit computation of standardized mean differences. As shown in Table 1, the two groups showed large differences, not only in beta-blocker use but also in history of variceal bleeding, portal vein thrombosis, and portosystemic collaterals (higher in the TIPS group). Importantly, large differences were found in the occurrence of grade $\geq 3$ postoperative complications within 1 month after surgery (lower in the TIPS group). Thus, it cannot be excluded that patients who underwent decompression had more severe portal hypertension before TIPS positioning and that preemptive TIPS reduced the occurrence of severe postoperative complications and/or allowed the achievement of long-term outcomes comparable to patients with less severe complications. The results need to be confirmed on larger, ideally prospective, cohorts and should not discourage the use of this 
technique in the care of preoperative patients. Moreover, preemptive TIPS could also be an important measure to increase surgical eligibility for complex operations by diminishing intraoperative bleeding and allowing a technically less demanding dissection. (2) In patients undergoing splenectomy, a pre-emptive calibrated TIPSS could reduce the incidence of portal vein thrombosis (postoperative rate of $50 \%$ in Elkrief et al.). Hence, even though conclusive data on the postoperative benefit of preemptive TIPS in these patients are still lacking, a potential benefit in the surgical feasibility and severe postoperative complications should be considered in the preoperative workup.

Acknowledgment: This work was supported by ARC grants (TheraHCC, TheraHCC2.0 IHUARC IHU201301187, and IHUARC2019 IHU201901299).

\section{REFERENCES}

1) Elkrief L, Ferrusquia-Acosta J, Payancé A, Moga L, Tellez L, Praktiknjo M, et al. Abdominal surgery in patients with idiopathic noncirrhotic portal hypertension: a multicenter retrospective study. HePATOLOgY 2019 Mar 29. doi: 0.1002/hep.30628.

2) Lahat E, Lim C, Bhangui P, Fuentes L, Osseis M, Moussallem T et al. Transjugular intrahepatic portosystemic shunt as a bridge to non-hepatic surgery in cirrhotic patients with severe portal hypertension: a systematic review. HPB (Oxford). 2018 Feb;20(2):101109. 


\section{Clinical features}

Male

Age

0.0204

Age-adjusted Charlson Comorbidity Index

0.0669

ASA score

0.0579

At least one extrahepatic comorbidity

$-0.2375$

associated with INCPH

History of ascites

0.085

Ascites at surgery

Absent

Controlled with diuretics

0.1611

Clinically detected

\section{Endoscopic data}

Previous variceal bleeding

0.8493

\section{Treatments}

Anticoagulation therapy

0.1684

Antiplatelet agents

$-0.3822$

Diuretic agents

0.1586

Beta blockers

$-1.2448$

\section{Imaging data}

Portal vein thrombosis

0.8023

Portosystemic collaterals at imaging

0.7977

This article is protected by copyright. All rights reserved 


\section{Laboratory data}

Platelets

$-0.1287$

Hemoglobin

$-0.0096$

INR

0.1019

Serum bilirubin

Serum creatinine

$-0.0273$

Serum albumin

$-0.0664$

MELD score

0.056

\section{Surgical data}

Major surgery

Minor surgery

$-0.2357$

Emergency procedures

0.1611

\section{Postoperative outcomes}

Occurrence of $\geq 1$ grade $\geq 3$ postoperative

complication within 1 month after surgery

Occurrence of $\geq 1$ portal hypertension-related

complication within 3 months after surgery

Death within 6 months after surgery

Unfavorable outcome

$-0.0367$

Effect size values $<0.1$ indicated very small differences; between 0.1 and 0.3 indicated small differences, between 0.3 and 0.5 indicated moderate differences and $>0.5$ indicated large differences (in bold). Effect size for continuous variables were calculated after estimation to mean and SD and log transformation (Wan X, Wang W, Liu J, Tong T. Estimating the sample mean and standard deviation from the sample size, median, range and/or interquartile range. BMC Med Res Methodol. 2014 Dec 19;14:135.)

Abbreviations: ASA,American Society of Anesthesiologists : INR, international normalized ratio; MELD, Model for End-Stage Liver Disease.

This article is protected by copyright. All rights reserved 
TABLE 1. Effect Size for the Comparison of the Patients With/Without Portal Decompression Before Surgery

This article is protected by copyright. All rights reserved 